\title{
The Exchange Rate Risk and Financial Sector Performance: Evidence from Nigeria
}

\author{
KOLAPO T. Funso ${ }^{1}$, Naheem Abiola Lawal ${ }^{2}$ \\ ${ }^{1}$ Faculty of Management Sciences, Ekiti State University, Ado-Ekiti, Nigeria \\ ${ }^{2}$ Institute of Graduate Studies, Istanbul Aydin University, Istanbul, Turkey \\ realvega1959@gmail.com, bodiatic@gmail.com
}

\begin{abstract}
This article looked at the connection between exchange rate risk and financial sector performance in Nigeria using time series data from 2008Q1 to 20017Q4. The study employed Autoregressive Conditional Heteroskedasticity (ARCH), and Granger Causality tests as estimation techniques. Financial intermediation index was used as the dependent variable while risk from exchange rate, risk from consumer price index and risk from interest rate were used as the independent variables. The findings from the study showed that exchange rate risk (EXR) coefficient value was -0.276230 with p-value of 0.0000 , implying that EXR was negative and significant to influence FII. The risk from financial intermediation index reveals a coefficient value of -5.213590 and the $p$-value of 0.000 implying that when financial intermediation index increases, volatility or risk reduces which means that financial intermediation index was not a risky variable which was significant during the study period. However, the study concluded that the shock from exchange rate moves at a negative and significant direction to financial intermediation index of the economy. It is also concluded that exchange rate and financial intermediation index does not have uni or bi-directional relationships between each other. It is recommended that the Government and the Apex Bank of Nigeria are encouraged to increase the stabilization measurement for exchange rate to cushion its risk and by so doing; this could improve financial sector performance.
\end{abstract}

Keywords: Exchange, Risk, Financial Intermediation Index, and Granger Causality.

\section{Introduction}

The exchange rate movement in the financial sector performance and other sectors of the economy cannot be belittled. Armitage, Wold and Weissle (2002) are of the view that exchange rate fluctuations endanger firms' performance most especially financial institutions. An upward movement of foreign exchange in any economy will have an adverse effect on all the sectors, thereby resulting to price instability and soften growth of the economy. Exchange rate measures a country currency in terms of other countries' currencies. The essence of this is to allow international trade between two or more countries because the world is now a global village and no nation is self-sufficient. Meanwhile, exchange rate risk has been seen a fundamental issue affecting every sector of the Nigerian economy. This risk arises from the untold fluctuation of foreign exchange. Nzioka and Maseki (2017) defined exchange rate risk as an exposure of an institution to the fluctuation of foreign exchange rates. In Nigeria, exchange rate has been moving in a significant upward direction since the 1980s. Recently, in the last quarter of 2015 to the first and period 1 \& 2 of the second quarter of 2016, the Nigerian official exchange rate to Dollar was $\$ 197$ after which oscillated in the period 3 of the second quarter to $\$ 283$. It was $\$ 313$ at the beginning of quarter 3 of 2016 which was later stabilized at $\$ 305$ at the end of the quarter three to the fourth quarter.

Meanwhile, it was fluctuating from $\$ 258$ to $\$ 55$ at the start of the first quarter to the end of the quarter of 2016 in the foreign market. This has left Nigeria business environment, including the banking sector to experience the high variation in the foreign exchange rate as Nigeria Naira depreciates against the key currency of US Dollar. Since businesses could source their input and sale globally, the risk or variation of foreign exchange rate has affected them, and this has called for the relevant authority to introduce various measures to mitigate the variation in foreign exchange rate. Despite the series of measurement on exchange rate risk, prices have not return to normal nor reduce to the minimum level and this in turn affecting the performance of financial sector and other sectors of the economy. However, empirical literature has shown that few articles had been written on the exchange rate risk and financial sector performance in different countries most importantly in the developing countries such as Ngerebo (2011); Runo (2013); He, Fayman \& Casey (2014); Shaofang \& Matej (2014); Sayedi (2014); Isaac (2015); Ahmed (2015); Ekinci (2016); Mansyur (2017); and Nzioka \& Maseki (2017). Most of them have looked at the internal exchange risk factors on financial sector performance while some looked at the external factors. 


\section{Literature Review}

Levine, Loayza and Beck (2000) studied the connection between financial intermediation and economic growth using dynamic panel techniques, and their findings revealed that financial intermediary components was positively connected with growth. Ngerebo (2011) wrote on the foreign exchange fluctuation on bank intermediation role in Nigeria from 1979-2004. Regression and correlation analyses were used. The study found that there exist positive association-ship between foreign exchange and bank intermediation role. Solakoglu and Demir (2009) also examined the connection between exchange rate exposure and financial sector in Turkey. Binary logistic method was used, and the result indicated that family ownership indicates a vital role in the exposure of the exchange rate. Furthermore, Runo (2013) studied the connection between exchange risk and oil companies' profitability. Correlation and regression analysis were employed as estimation techniques. The results showed that the risk from exchange greatly affects profitability. The risk was found to higher variance in forecasting the profit of these firms and exhibits a positive connection. Nonetheless, Shaofang and Matej (2014) focused on financial derivatives and US bank risks from 1997 to 2012 using pooled regression model were. It was found that financial derivatives positively related to Bank Holding Companies' systematic risk exposures. The result further revealed that higher interest rate, credit derivatives and exchange rate correspond to greater systematic risk.

He et al. (2014) investigated foreign currency instabilities on bank profitability in the US over a 40-year period. They used regression analysis to examine the broad objective. The result revealed that commercial banks are affected by the fluctuations from foreign exchange. Similarly, Sayedi (2014) focused on the effect of credit risk, market power, the exchange rate on the profitability of Nigeria banks between 2006 and 2011. Linear regression analysis was employed as the estimation technique. The findings revealed that market power has a positive and significant effect, exchange rate exhibits a positive and insignificant effect, while credit risk has a negative and insignificant effect on profitability of bank performance. Aspal and Dhawan (2014) wrote on financial performance assessment of banking sector in India from 2007 to 2012 using CAMELs ranking method on the selected banks. The rating results among the private banks revealed that 6 out of the banks show excellent performance in India. More so, their findings have not been consistent due the time period covered and the methodology. This however prompted this study to further re-examine exchange rate risk and financial sector performance in Nigeria. More so, Isaac (2015) studied the exchange rate risk impact on the performance of banks in Nigeria from 1997-2013. The study employed OLS as the estimation technique. The findings revealed the exchange rate risk and bank performance have significant association-ship.

Ekinci (2016) focused on the credit and market risks on the performance of banks in Turkey using weekly data from 2002 to 2015. The study employed generalized autoregressive conditional heteroscedastic (GARCH) method. The findings revealed that credit risk was to negative and insignificant, foreign exchange risk was positive and insignificant, while market risk is significantly positive on the performance of bank in Turkey. Continuously, Lagat and Nyandema (2016) studied exchange rate variations on financial performance of Nairobi banks from 2000 to 2013. The study employed correlation and multivariate regression as estimation techniques. The result discovered that exchange rates have positive relationship with financial performance indicators during the study period. In the same view, Osundina, Osundina, Jayeoba and Olayinka (2016) investigated the relationship between exchange rate volatility and Nigeria banks' performance from 2005 to 2014. ARCH-LM, fixed and random effect and Huasman test were employed in this study. The study showed that the fluctuations from the exchange rates revealed insignificant impact on bank profitability. Mansyur (2017) focused on the financial risk on banks' financial performance in Indonesia from 2011 to 2015. The study employed path analysis, and the findings revealed that liquidity and exchange risks does not affect the performance of banks while credit risk and interest risk were significant but moving in a negative and positive directions respectively.

\section{Methodology}

Secondary data were employed and sourced from the statistical bulletin of the Central Bank of Nigeria (CBN) from the first quarter of 2008 to the last quarter of 2017. This period marks a rising movement in the exchange of Naira against other currencies of the world, particularly the key currencies. The study adapted 
the work of Isaac (2015), he carried out an investigation on the exchange rate risk impact on bank performance in Nigeria from 1997-2013. The model for the study was specified in panel form as follows:

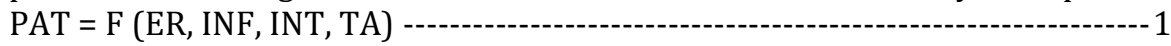

Where:

PAT $=$ Profit after Tax

$\mathrm{ER}=$ Exchange rate

$\mathrm{INF}=$ Inflation rate

INT $=$ Interest rate

$\mathrm{TA}=$ Total asset of the bank

However, the above model was re-modified into a time series, functional model where the financial performance was used as the dependent variable, and it was proxy with the Financial Intermediation Index (FII) of the shareholders' equity while risk from exchange rate, risk form interest rate, and risk from consumer price index were used as the independent variables. The model is presented as follows:

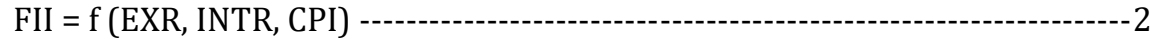

Where

FII $=$ Financial Intermediation Index

EXR $=$ Risk from Exchange Rate

INTR $=$ Risk from Interest Rate

$\mathrm{CPI}=$ Risk from Consumer Price Index

The econometric form of the model is presented as:

$\mathrm{FII}=\eta_{0}+\eta_{1} \mathrm{EXR}+\eta_{2} \mathrm{INTR}+\eta_{3} \mathrm{CPI}+\varepsilon_{\mathrm{t}}-\cdot-\mathrm{-}$

Where

$\eta_{0}=$ Intercept

$\eta_{1}-\eta_{3}=$ Shift Parameters and $\varepsilon_{t}=$ error term at period $\mathrm{t}$

\section{Results and Discussion of Findings}

Stationarity Result

Table 1: ADF-Test

\begin{tabular}{ll}
\hline Variable & Integration Order \\
\hline FII & $1(0)$ \\
INR & $\mathrm{I}(1)$ \\
EXR & $\mathrm{I}(2)$ \\
CPI & $\mathrm{I}(2)$ \\
\hline
\end{tabular}

Source: Author's compilation (2019)

Augmented Dickey Fuller test was used to carry out the stationarity of the variables employed in this study. The result revealed that the financial intermediation index used as the proxy for financial performance was stationary at level. However, interest rate was not stationary at level, but when converted to the first difference, it became stationary. The exchange rate and consumer price index were stationary at the second difference during the study period.

Autoregressive Conditional Heteroskedasticity (ARCH)

Table 2: ARCH Result

Predictor Variable: FII

GARCH $=$ C(4) + C(5)*RESID(-1)^2 + C(6)*GARCH(-1) + C(7)*INR + C(8) *CPI

\begin{tabular}{lllll} 
Variable & Coefficient & Std. Error & z-Statistic & Prob. \\
\hline @SQRT(GARCH) & -5.213590 & 0.000150 & -34658.49 & 0.000 \\
C & 173.2182 & 0.004688 & 36946.39 & 0.000 \\
EXR & -0.276230 & 0.004771 & -57.89522 & 0.000 \\
C & Variance-Equation & & & \\
\hline
\end{tabular}




\begin{tabular}{lllll}
\multicolumn{5}{c}{$\begin{array}{l}\text { Journal of Economics and Behavioral Studies (ISSN: 2220-6140) } \\
\text { Vol. 12, No. 1, pp. 1-6, February 2020 }\end{array}$} \\
\hline \multicolumn{5}{c}{} \\
\hline RESID(-1)^2 & 0.357354 & 0.014625 & 24.43386 & 0.000 \\
GARCH(-1) & -0.126858 & 0.009444 & -13.43319 & 0.000 \\
INR & 26.64262 & 2.296167 & 11.60308 & 0.000 \\
CPI & -2.621770 & 0.215131 & -12.18686 & 0.000 \\
R-squared & 0.588612 & Adjusted R-squared & 0.565758 \\
\hline
\end{tabular}

Source: Author's computation (2019)

The table above shows the auto-regressive conditional heteroskadasticity (ARCH) result and the result revealed that the square root of GARCH (@SQRT(GARCH)) which shows the standard deviation of financial intermediation index or the risk from financial intermediation index reveals a coefficient value of -5.213590 and the p-value of 0.000 implying that when financial intermediation index increases, volatility or risk reduces which means that financial intermediation index was not a risky variable, and it was significant during the study period. Meanwhile, the EXR coefficient value was -0.276230 and its p-values are 0.000 . This implies that EXR was positive and significant to influence FII. This also means that the shock coming from exchange rate moves at a negative and significant direction to the financial intermediation index of the economy. The variance equation result revealed that the coefficient of $\operatorname{RESID}(-1)^{\wedge} 2(\mathrm{ARCH})$ value was 0.357354 and its p-value was 0.000 indicating that ARCH effects was positive and significant.

This also connotes that there exist ARCH effect or the internal shock of FII can influence the volatility of financial intermediation index in the model. The coefficient value of GARCH(-1) was -0.126858 with p-value of 0.000 meaning that GARCH(-1) which also refers to as the internal cause was negative and significant. This means that financial intermediation index is affected with GARCH effects during the study period. Interest rate and CPI used as the external causes or factors in this model revealed the coefficient value INR was 26.64262 with the p-value of 0.0000 implying that interest rate was positive and significant to the standard deviation or volatility of financial intermediation index. The consumer price index coefficient value was 2.621770 and its p-value is 0.0000 . This indicates that consumer price index as an external cause was negative and significant to the volatility of financial intermediation index during the study period.

Fig1: Normality Test, Residual Diagnostic Tests

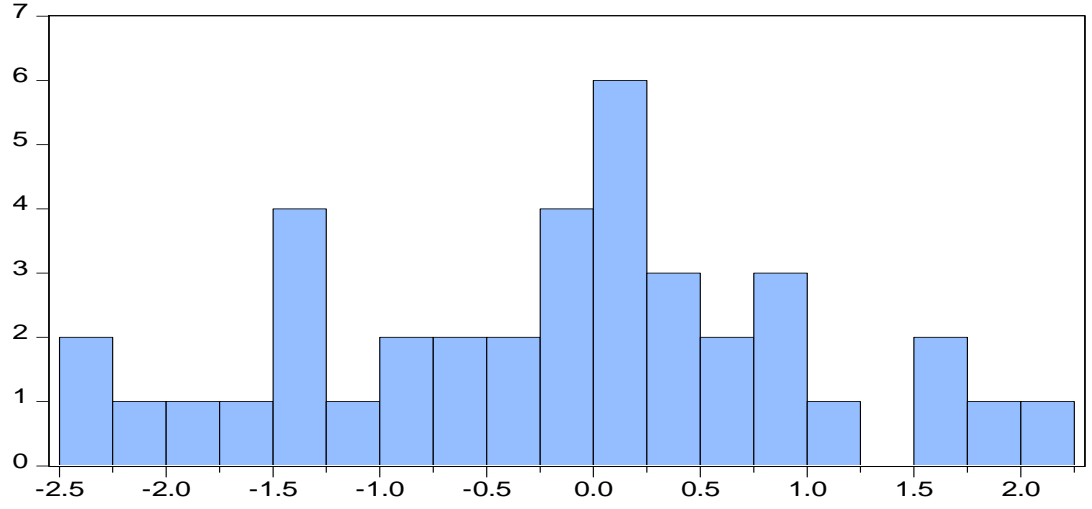

Series: Standardized Residuals Sample 2008Q2 2017Q4 Observations 39

$\begin{array}{lr}\text { Mean } & -0.186002 \\ \text { Median } & -0.046961 \\ \text { Maximum } & 2.221124 \\ \text { Minimum } & -2.488017 \\ \text { Std. Dev. } & 1.144664 \\ \text { Skewness } & -0.076028 \\ \text { Kurtosis } & 2.498551 \\ & \\ \text { Jarque-Bera } & 0.446180 \\ \text { Probability } & 0.800043\end{array}$

This figure shows the normality test of the variables employed. It was showed that the JB value is 0.446180 and its prob. value is 0.800043 which means that variables are normally distributed during the study period.

Table 3: Heteroscedastic Test

\begin{tabular}{|c|c|c|c|}
\hline Heteroskedast & $\mathrm{CH}$ & & \\
\hline F-stat & 0.739622 & Prob. F(1,36) & 0.3955 \\
\hline Obs*R-squared & 0.764996 & Prob. Chi-Square(1) & 0.3818 \\
\hline
\end{tabular}

Source: Author's compilation (2019)

This shows the report of hetoeroskedasticity test and the result from the observed R-squared probability chisquare values are 0.764996 with the p-values of 0.3818 which implies that the null hypothesis is failed to be rejected at $5 \%$ level of significance that the residual does not have ARCH effects. 
Table 4: Autocorrelation Test

\begin{tabular}{|c|c|c|c|c|c|c|}
\hline Auto-correlation & Partial Co & & AC & PAC & Q-Stat & Prob* \\
\hline $.1^{*}$ & $.1^{*}$. & 1 & .139 & .139 & .8141 & .367 \\
\hline$*||$. &.$*||$. & 2 & -.107 & -.129 & 1.3065 & .520 \\
\hline.$||$. & .1 .1 & 3 & .036 & .074 & 1.3649 & .714 \\
\hline$* *||$. & $* *||$. & 4 & -.235 & -.277 & 3.8788 & .423 \\
\hline$* * *||$. & $* *||$. & 5 & -.394 & -.330 & 11.189 & .048 \\
\hline$*^{*} .1$ & .1 .1 & 6 & -.071 & -.057 & 11.430 & .076 \\
\hline.$* 1.1$ &.$^{*} .1$ & 7 & -.083 & -.179 & 11.774 & .108 \\
\hline. $\mid .1$ &.$*|\cdot|$ & 8 & -.050 & -.087 & 11.902 & .156 \\
\hline$.\left.\right|^{*} . \quad \mid$ & .1 .1 & 9 & .165 & -.037 & 13.345 & .148 \\
\hline$.\left.\right|^{* *} \quad \mid$ & .1 .1 & 10 & .219 & .039 & 15.991 & .100 \\
\hline .1 .1 &.$*||$. & 11 & -.015 & -.138 & 16.003 & .141 \\
\hline .1 .1 &.$*||$. & 12 & -.044 & -.160 & 16.117 & .186 \\
\hline$.\left.\right|^{*} . \quad \mid$ & .1 .1 & 13 & .075 & .029 & 16.462 & .225 \\
\hline .1 .1 & .1 .1 & 14 & -.032 & .007 & 16.528 & .282 \\
\hline . |*. $\mid$ & $.\left.\right|^{* *} \quad \mid$ & 15 & .084 & .215 & 16.997 & .319 \\
\hline$\omega^{*}$ &.$\left.\right|^{*}$. & 16 & .156 & .140 & 18.681 & .286 \\
\hline
\end{tabular}

Source: Author's compilation (2019)

The above table displays the absence of autocorrelation and partial correlation in the variables employed during the study period.

Table 5: Pairwise Granger Causality Result

\begin{tabular}{llll}
\hline Null Hypothesis: & & F-Statistic & Prob. \\
\hline No causality between INR and FII & 37 & .07743 & 0.9257 \\
No causality between FII and INR & & 3.51322 & .0417 \\
No causality between EXR and FII & 37 & .53991 & .5880 \\
No causality between FII and EXR & & .09446 & .9101 \\
No causality between CPI and FI & 37 & .15087 & .8606 \\
No causality between FII and CPI & & 3.99167 & .0283 \\
No causality between EXR and INR & 42 & .44788 & .6424 \\
No causality between INR and EXR & & 1.07311 & .3523 \\
No causality between CPI and INR & 42 & 2.51210 & .0948 \\
No causality between INR and CPI & & .77310 & .4689 \\
CPI does not Granger Cause EXR & 42 & 2.70852 & .0798 \\
No causality between and CPI & & 6.78841 & .0031 \\
\hline
\end{tabular}

Source: Author's compilation (2019)

The Pairwise Granger Causality Test Presented in the table above revealed that interest rate to financial intermediation index value was 0.9257 implying that interest rate does not granger cause financial intermediation index. The p-value of financial intermediation index to interest rate was 0.0417 meaning that financial intermediation index can granger cause interest rate. That is, there exist a uni-directional connection between financial intermediation and interest rate. The p-value of exchange rate to financial intermediation index was 0.5880 and financial intermediation index to exchange was 0.9101 . This indicates that there is no uni or bi-directional connection between EXR and FII vise-a-viz. it also indicates that there is uni-directional relationship between financial intermediation index and consumer price index that is FII can granger cause CPI, but CPI does not granger cause FII. The result of exchange rate and interest rate revealed that there exist no uni or bi-directional relationship between EXR and INR. More so, CPI and interest rate reveal that they free move to each other. That is, they did not granger cause one another during the study period. Also, the $\mathrm{p}$ values of consumer price index and exchange rate were 0.0798 indicating that at $5 \%$ consumer price index does not granger cause exchange rate. The p-value of exchange rate and consumer price index was 0.0031 implying that the EXR can granger cause CPI. This connotes that there exists uni-directional connection between the EXR and CPI during the study period. 


\section{Conclusion and Recommendations}

This study studied the connection between exchange rate risk and financial performance in Nigeria. Several empirical reviews were being reviewed in the literature to identify the unfilled gap. Meanwhile, the findings have revealed directional connection between exchange rate and financial performance proxy with financial intermediation index and some other variables such as exchange rate, interest rate and consumer price index. However, the study concluded that the shock from exchange rate moves at a negative and significant direction to the financial intermediation index of the economy. It is also concluded that exchange rate and financial intermediation index do not have uni or bi-directional relationship between each other. The study further concluded that interest rate and consumer price index have significant effect to the volatility of financial intermediation index during the study period. The study recommended that the Government and the Apex Bank of Nigeria should introduce to increasing the stabilization measurement for exchange rate to cushion its risk and by so doing; this could improve on the performance of the financial sector. Also, the slight bidirectional relationship between consumer price index and exchange rate could be used as a measuring factor in curbing the risk from foreign exchange, that is, when consumer price index reduces, foreign exchange rate reduces and when it increases, foreign exchange rate could also increase.

\section{References}

Ahmed, L. (2015). The Effect of Foreign Exchange Exposure on the Financial Performance of Commercial Banks in Kenya. International Journal of Scientific and Research Publications, 5(11), 115-120.

Armitage, J. C., Wold, P. J. \& Weissler, R. (2002). Adjustments for Changes in Exchange rates During an Advance Pricing Agreement Term unpublished Thesis.

Aspal, P. K. \& Dhawan, S. (2014). Financial performance assessment of banking sector in India: A case study of old private sector banks. The Business \& Management Review, 5(3), 196-211.

Ekinci, A. (2016). The Effect of Credit and Market Risk on Bank Performance: Evidence from Turkey. International Journal of Economics and Financial Issues, 6(2), 427-434.

He, L. T., Fayman, A. \& Casey, K. M. (2014). Bank Profitability: The Impact of Foreign Currency Fluctuations. Journal of Applied Business and Economics, 16(2), 98-104.

Lagat, C. C. \& Nyandema, D. M. (2016). The Influence of Foreign Exchange Rate Fluctuations on the Financial Performance of Commercial Banks Listed at the Nairobi Securities Exchange. British Journal of Marketing Studies, 4(3), 1-11.

Levine, R., Loayza, N. \& Beck, T. (2000). Financial intermediation and growth: Causality and causes. Journal of Monetary Economics, 46(1), 31-77.

Isaac, L. (2015). Assessing the Impact of Exchange Rate Risk on Banks Performance in Nigeria. Journal of Economics and Sustainable Development, 6(6), 1-14.

Mansyur, N. (2017). Impact Financial Risk on Financial Performance Bank in Indonesia. The International Journal of Business \& Management, 5(10), 305-310.

Ngerebo, T. A. (2011). The impact of foreign exchange fluctuation on the intermediation of banks in Nigeria (1970 - 2004). African Journal of Business Management, 6(11), 3872-3879.

Nzioka, O. M. \& Maseki, F. M. (2017). Effects of Hedging Foreign Exchange Risk on Financial Performance of Non-Banking Companies Listed at the Nairobi Securities Exchange. European Scientific Journal, 13(10), 402-416.

Osundina, C. K., Osundina, J. A., Jayeoba, O. O. \& Olayinka, I. M. (2016). Exchange Rate Volatility and Banks Performance: Evidence from Nigeria. International Journal of Economics and Business Management, 2(4), 1-11.

Runo, F. N. (2013). Foreign exchange risk and profitability of oil companies listed in the Nairobi Securities Exchange. Unpublished MBA Thesis. University of Nairobi.

Sayedi, S. N. (2014). Credit Risk, Market Power and Exchange Rate as Determinants of Banks Performance in Nigeria. Journal of Business and Management, 16(1), 35-46.

Shaofang, L. \& Matej, M. (2014). The Use of Financial Derivatives and Risks of U.S. Bank Holding Companies.

Solakoglu, M. N. \& Demir, N. (2009). Exchange-Rate Exposure and the Financial Sector. Journal of Economic and Social Research, 11(2), 29-42. 